\title{
Reproductive Biology and Bioturbatory Activities of Two Sympatric Species of Fiddler Crabs Uca lactea annulipes and Uca triangularis bengali (Decopada : Ocypodidae) at the East Midnapore Coastal Belt of West Bengal, India
}

\author{
Subhasish Chatterjee \\ Department of Zoology, Vidyasagar University \\ Midnapore (West) -721102, West Bengal, India \\ Tel: 91-943-421-6333Ｅ-mail: subhasish.vu@gmail.com
}

Tapas Kumar Das

Department of Zoology, Vidyasagar University

Midnapore (West) -721102, West Bengal, India

Susanta Kumar Chakraborty (Corresponding Author)

Department of Zoology, Vidyasagar University

Midnapore (West) -721102, West Bengal, India

Tel: 91-943-327-0591Ｅ-mail: susantachakraborty@yahoo.com

Received: March 3, 2014 Accepted: March 19, 2014

doi:10.5296/jbls.v5i2.5809 URL: http://dx.doi.org/10.5296/jbls.v5i2.5809

\begin{abstract}
Two sympatric species of fiddler crabs viz. Uca lactea annulipes and Uca triangularis bengali belonging to order decapoda, family ocypodidae have been taken into consideration in respect of their habitat preference, sex ratio, fecundity and role of bioturbatory activities in sustaining the coastal-estuarine-ecosystem dynamics at an ecotone (Talsari) located in the Midnapore
\end{abstract}


(East) coastal belt of West Bengal, India. A distinct segregation of habitats of these two species was evident from this field study. In general, monthly sex ratios were found to be clearly male biased for both species. Reproductive potential and intensity of the studied fiddler crabs have been measured by quantifying the relative frequency of ovigerous females and their fecundities. These two crabs have been observed to act as excellent bioturbator mediators and their bioturbatory activities were found to alter geochemistry of sediments by way of making semidomes (only male of $U$. lactea annulipes) and mudballs (both sexes of $U$. triangularis bengali). These bioturbatory structures used to play some roles in the social as well as sexual interactions of both species.

Keywords: Fiddler crabs, Sex ratio, Fecundity, Bioturbation

\section{Introduction}

In many tropical environments more than one species of $U c a$ coexist in similar habitats. They may have different patterns of microhabitat preferences, so that their ecological niches are not identical (Backwell et al., 2006). In this study, ecological characteristics of two sympatric species of Uca lactea annulipes and Uca triangularis bengali at the Talsari of the East Midnapore coastal belt of West Bengal, India were studied to note how their different ecological and ethological features by prevaling different density dependant and independant parameters.. Fiddler crabs (Ocypodidae, Uca) are a well-known group of small, intertidal brachyuran crabs (Backwell \& Christy, 2000). They are widely distributed in nearly all tropical and subtropical regions of the world. Fiddler crabs burrow in intertidal areas and are important consumers of detritus, bacteria, fungi, and benthic microalgae in coastal marsh, mangroves, sand flat, and mudflat habitats (Backwell et al., 2006). Fiddler crabs are intertidal animals that live in mangrove forests, tidal creeks, sandbars, mudflats or, occasionally, stone or boulder beaches. They can occur in huge numbers, with thousands of individuals living in small, adjacent territories. Their burrowing activities aerate the soil and enhance the growth of marsh plants. Their presence also increases the amount of meiofauna in salt marshes (Burford et al., 2001). Fiddler crabs have long been a favourite animal for ecological studies (Christy et al., 2001). They are highly social animals with a rich behavioural repertoire. These crabs are best known for their remarkable sexual dimorphism: males have highly asymmetrical claws (chelipeds), with the major claw greatly enlarged (up to five times in length) relative to both the male's own minor claw and the female's two symmetrical minor claws (Rosenberg, 2002; Sweat, 2009). The major cheliped may constitute up to $48 \%$ of an adult male's body mass and is considered a classic example of sexual selection (Pope, 2005; How et al., 2008). The claw is used for mating displays and in combat with other males. Another conspicuous difference is the form of the abdomen. In most male crabs; this is narrow and triangular in form, while females have a broader, rounded abdomen (Guillermo Guerao \& Guiomar Rotllant, 2009). This is due to the fact that female crab's brood fertilized eggs on their pleopods. Several taxonomic and ecological works on fiddler crabs of Hooghly-Matla estuarine complex and other coastal areas of India have been reported (Chakraborty \& Choudhury, 1992). Fiddler crabs are diurnally active (Macia et al., 2001; Mokhtari et al., 2007). Surface activity terminates when the tide covers the area and the crabs retreat into their burrows and plug the entrances with sediment. Fiddler crabs, an important faunal component in the food web of the coastal belt play a 
significant positive role in maintaining the steady state of the ecosystem and enhance its biological potentiality through accelerating the decomposition cycle as macro decomposers (Chatterjee \& Chakraborty, 2014) influencing the ecosystem function to a large extent and are morphologically, physiologically and behaviorally well adapted to their environment. The burrow is a very important resource for the crabs (Zeil \& Layne, 2002). It offers protection from aquatic predators during high tide and from aerial and terrestrial predators during low tide, when the crabs are active on the surface. It provides a safe refuge for moulting animals and for females while incubating their eggs. The burrow protects the crabs from desiccation during their activity on the surface by offering them access to water, which is needed for respiration and feeding. The burrow walls are important sites for nitrification and de-nitrification processes in the sediment. The burrow also serves as central hub from where the crabs venture out on their feeding excursions (Hemmi \& Zeil, 2003). Fiddler crabs by their sheer numbers and abundance are a rich food source for birds (Zeil et al., 2006). They form important links between the primary detritus at the base of the food web and consumers of higher trophic levels (Koch \& Wolff, 2002). Fiddler crabs being the most abundant and conspicuous invertebrates in many salt marshes (Montague, 1980), ecologically influence the salt marsh significantly by transferring of energy and nutrients within the marsh ecosystem (Daiber, 1982). Uca lactea annulipes and Uca triangularis bengali showed their co-existence with Suaeda maritima and Salicornia brachiat at present study site. Most of fiddler crabs from temperate and tropical estuaries, male to female ratios significantly exceeding unity have been documented by several researchers (Johnson, 2003). Males may be four times more abundant than females in some species (Emmerson, 1994). Generally, natural selection favours a sex ratio of 1:1 parental expenditure on offspring (May, 1983). Although deviant sex ratios are common in marine crustacean, owing to sequential hermaphroditism, sex specific habitat use, and differential growth rate (Johnson, 2003), the trend in Uca is notable in its widespread and consistent bias toward males. Male fiddler crabs are both territorial and promiscuous conditions that should favour female biased sex ratios. Ovigerous females spend prolonged periods underground and, when on the surface, often forage to closer to water sources, creating spatial separation from foraging males (Montague, 1980). Reproduction is the main mechanism that keeps species continuity so that it contributes to regulate the population size. Adaptations on mating systems jointly with environmental conditions are also factors that influence fiddler crab fecundity (Costa et al., 2006). Ovigerous females of two crabs were used to achieve and compare their reproductive pattern. The presence of ovigerous and non ovigerous female provided one index of reproductive periodicity. Fecundity in brachyuran crabs is commonly defined as the number of eggs produced per female per clutch (Reid \& Corey, 1991). In brachyurans, body size is the main determinant of fecundity and it does depend on the allometric constraints on yolk storage within the cephalothorax (Lim, 2006).

The term 'Bioturbation' originates from ichnology, to describe traces of life in fossil and modern sediments, and has subsequently been adopted in soil and aquatic sciences (Meysman et al., 2006; Chatterjee et al., 2008; Wilkinson et al., 2009). Sedimentary environments are dynamic habitats where the sediments, the fundamental building blocks of the habitats, are continually structured both by the local physical regime. Both in terrestrial and aquatic environment, animal bioturbation results from comparable activities, including burrow and 
mound construction, the lateral 'ploughing' of the surface (e.g. by moles or heart urchins), particle ingestion and egestion during foraging (e.g. deposit feeding, geophagy or lithophagy), food caching and prey excavation, wallowing and trampling, and the infilling of abandoned burrow structure (Meysman et al., 2006). In modern ecological point of view, bioturbation is now recognized as an archetypal example of 'ecosystem engineering' (Meysman et al., 2006; D' Andrea \& DeWitt, 2009) and act as major modulators of microbial activities and biogeochemical processes in aquatic environments (Mermillod-Blondin 2011).

Seasons are well pronounced in the coastal environment each with four months duration, Pre monsoon (March to June) with least rainfall and high temperature; monsoon (July to October) with high rainfall and moderate temperature; and post monsoon (November to February) with occasional rainfall and low temperature. The present investigation was undertaken to identify the habitat preference, sex ratio, fecundity and different features of bioturbatory activities during different seasons among the different tidal levels viz. LTL (Low Tidal level), MTL (Mid Tidal level), HTL (High Tidal level).

\section{Materials and Methods}

\subsection{Physiography of Study Site}

The coastal tract of Midnapore (East) West Bengal, India extends from the junction of longitudinal extension $87^{\circ} 20^{\prime} \mathrm{E}$ to $88^{\circ} 5^{\prime} \mathrm{E}$ and latitudinal extension $21^{\circ} 30^{\prime} \mathrm{N}$ to $22^{\circ} 2^{\prime} \mathrm{N}$ (Chakraborty et al., 2012). The present study was conducted at Talsari, an ecotone located at the confluence of Subarnarekha estuary with Bay of Bengal, between 21 $35^{\prime} 48^{\prime \prime}$ Northern Latitude and $87^{\circ} 27^{\prime} 17^{\prime \prime}$ Eastern Longitude (Figure 1). This site is characterized in having mixed sand and mudflats endowed with degraded mangroves. The Subarnarekha estuarine delta is the westernmost unit of the topographic expression in the present coastal plain. A tract of mangrove swamp is situated around the estuary link of Talsari tidal channel and extensive saltmarsh tract extends on the more saline flats of eastward tidal basin.

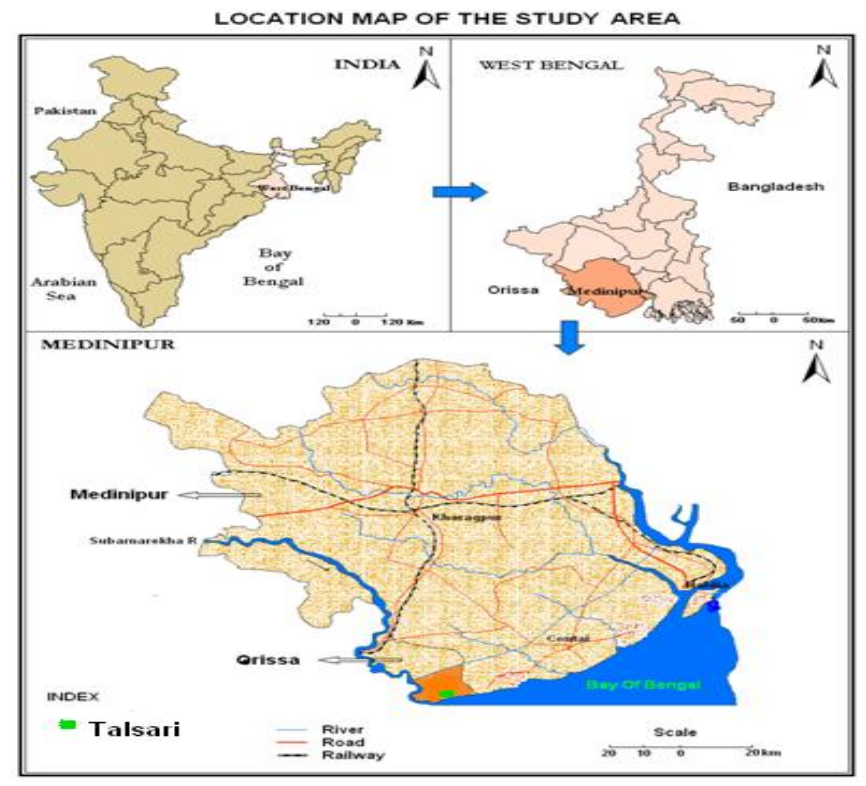

Figure 1. Map showing the location of study site 


\subsection{Duration of the Study Period}

Seasonal dynamics of reproductive parameters in respect of sex ratios ( $\mathrm{M}: \mathrm{F})$, size classes (carapace width-CW), fecundity and different features of bioturbatory activities of two species of fiddler crabs were investigated in the study site through different months and seasons during March, 2009 to February, 2010.

\subsection{Different Attributes of Sex Ratio, Size Class (Carapace Width) and Fecundity}

Samples were collected monthly during low tide period on full moon during day time over a period of approximately 1 hour duration and covering an area of about $500 \mathrm{~m}^{2}$ of the study site for the assessment of sex ratio. Fecundity (the number of eggs per female) determines the reproductive potential of a species and the stock size of its population. On each sampling occasion, a total of twenty quadrats $1.0 \mathrm{~m}^{2}(1.0 \times 1.0 \mathrm{~m})$ squares were set out at the study site. Ten quadrats were randomly chosen for sampling and each of which was completely excavated with a corer ( $0.08 \mathrm{~m}$ diameter) to a depth of $0.5 \mathrm{~m}$. Crabs were collected by using diving knives or shovel with a catch effort and all ovigerous females after being unearthed were preserved in $70 \%$ ethanol, bagged and stored until further processing. The carapace width $(\mathrm{CW})$ were measured using a vernier caliper $( \pm 0.05 \mathrm{~mm}$ accuracy) or, with the aid of a stereomicroscope $(\mathrm{CW}<10.0 \mathrm{~mm})$ respectively. To estimate fecundity, egg bearing females were selected for egg counting. Pleopods were removed from females, placed in Petri dishes filled up with seawater, and eggs were isolated by gradually adding a solution of sodium hypochlorite (7\%). Bare pleopods were then separated by gentle stirring in a beaker filled with $200 \mathrm{ml}$ seawater. Three sub samples $(1.5 \mathrm{ml})$ were taken using a pipette, and eggs were counted under a dissecting microscope. The average value obtained was then extrapolated for the whole suspension to estimate the total number of eggs (Litulo, 2004).

\subsection{Statistical Analyses}

Different statistical analyses were done by following standard book (Zar, 2009) and utilizing 'STATISTICA' (STATSOFT, 2001) with the help of a P-4 computer. Quantification of different sexual forms of two fiddler crabs under present study (male-M, ovigerous female-OF and non ovigerous female -NOF) was analyzed following Chi square test $(\chi 2$-test, $\mathrm{P}<0.01)$ to test the independence of attributes between sex and months of availability using the frequency data of abundance. Such analysis was repeated for each type of species. Many needful pair wise simple correlation coefficients were calculated and tested by t test e.g. carapace width vs. fecundity. Factorial ANOVA technique was used to compare the main effects of seasons and tidal levels of different characteristics of bioturbatory activities. Means of main effect were further subjected to Duncan's test at 5\% level of significance to test the homogeneity among respective means for each factor. Significance of all main and interaction effects were also tested by $F$ tests on the results derived from each ANOVA analysis. Significant main effects for factors having more than two levels were subjected to Duncan's test, where similar alphabets denote homogenous means at $5 \%$ level of significance.

\section{Results}

\subsection{Habitat Preference}


The habitats of two sympatric species of brachyuran, $U$. lactea annulipes and $U$. triangularis bengali showed their co-existence with the open mud flat endowed occasionally with saline herbs like Suaeda maritima and Salicornia brachiata. Both the species used to prefer a muddy marsh environment where the substrate is relatively free of dense underground networks of plant's roots,but also stable enough to allow for construction of burrows. They were collected from the study site (Talsari) with maximum abundance at MTL and HTL respectively and it was the dominant species in the middle part of the muddy intertidal belt. Table 1 has revealed soil textural composition of the habitat of each species.

Table 1. Soil texture of the habitat of each species (\%)

\begin{tabular}{|c|c|c|c|c|c|c|c|c|c|c|}
\hline & Texture $(\%)$ & \multicolumn{3}{|c|}{ Pre Monsoon } & \multicolumn{3}{|c|}{ Monsoon } & \multicolumn{3}{c|}{ Post Monsoon } \\
\hline \multirow{2}{*}{ Uca lactea annulipes } & & LTL & MTL & HTL & LTL & MTL & HTL & LTL & MTL & HTL \\
\hline \multirow{4}{*}{ Sand } & 89.6 & 91.9 & 91.5 & 87.2 & 89.2 & 95.5 & 86.8 & 88.2 & 82.2 \\
\cline { 2 - 12 } & Silt & 3.7 & 3.6 & 2.8 & 4.2 & 4.8 & 2.6 & 3.9 & 3.2 & 4.4 \\
\cline { 2 - 12 } & Clay & 6.7 & 4.5 & 5.7 & 8.6 & 6 & 1.9 & 9.3 & 8.6 & 13.4 \\
\hline Uca triangularis bengali & Sand & 91.2 & 92 & 91.5 & 96.6 & 93.2 & 95.5 & 84.6 & 84.3 & 82.6 \\
\hline & Silt & 4.2 & 3.6 & 4.2 & 1.58 & 3.14 & 2.8 & 8.2 & 5.5 & 4.6 \\
\hline & Clay & 4.6 & 4.4 & 4.3 & 1.84 & 3.62 & 1.7 & 7.2 & 10.2 & 12.8 \\
\hline
\end{tabular}

\subsection{Sex Ratio and Fecundity}

A total of 1313 individuals of $U$. lactea annulipes (752 males, 261 non-ovigerous females and 300 ovigerous females) were recorded during the study period. The number of crabs encountered and the monthly sex ratio of which has been listed in Table 2. In general, monthly sex ratios were found to be slightly male biased, except March, April, May, October, November and December during the study period. Among 300 ovigerous females of this species, 40 were used for fecundity studies (CW: 5.5-14.5), which showed a mean fecundity of 5930 \pm 3685 eggs and measured a mean size of $\mathrm{CW}(9.21 \pm 2.49)$. Number of eggs of each size class have been mentioned in Table 3. Males $(\mathrm{N}=752)$ were more abundant than females $(\mathrm{N}=561)$, but overall sex ratio (1:0.75) was significant deviate from the 1:1 ratio and month has significant effect on the allocation of different sexes $\left(\chi^{2}\right.$-test, $\mathrm{P}<0.01$, 99\% Table 4$)$. Fecundity variation relative to carapace width was fitted into a power function given by the equation $\mathrm{F}=1512 \mathrm{x}-8889$ and yielded a correlation coefficient of $\mathrm{R}^{2}=0.951$. The scatter plot representing this correlation is shown on Figure 2.

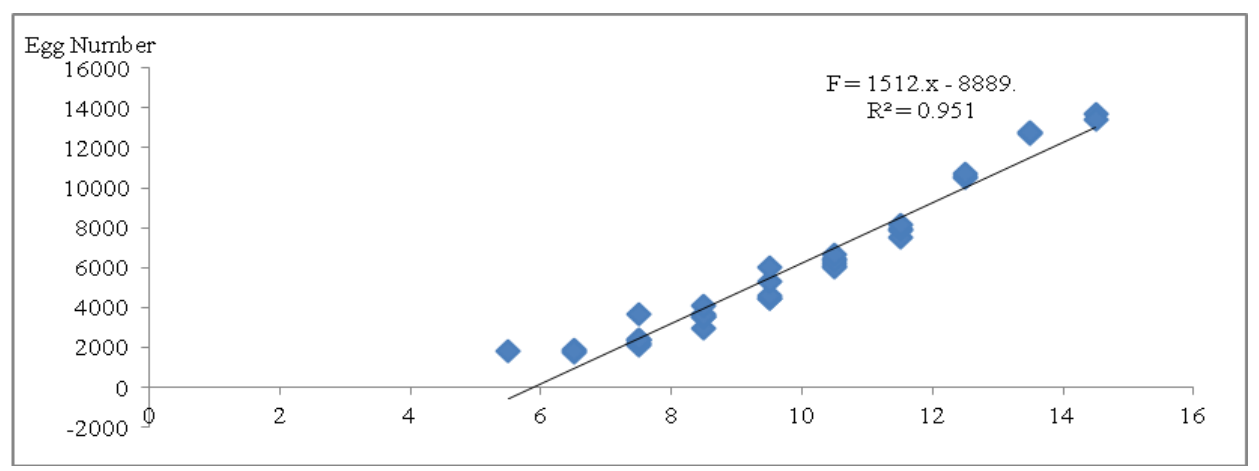

Figure 2. Relation between egg number and carapace width of $U$. lactea annulipes $(\mathrm{F}=$ 
fecundity, $\mathrm{R}^{2}=$ determination coefficient, $\mathrm{X}$ axis=carapace width, $\mathrm{Y}$ axis=Egg Number)

A total of 556 of $U$. triangularis bengali (296 males, 158 non ovigerous females and 102 ovigerous females) were obtained throughout the study period. The number of crabs encountered and the monthly sex ratio of which has been listed in Table 5. In general, monthly sex ratios were a little male biased, except July, October, November, December and January. Among 102 ovigerous females of this species, 38 were used for fecundity study, which bare a mean fecundity of $3768 \pm 2616$ eggs and measured a mean size of $8.68 \pm 2.22 \mathrm{CW}$. Number of eggs for each size class have been mentioned in Table 6. Males $(\mathrm{N}=296)$ were more plentiful than females $(\mathrm{N}=260)$, but overall sex ratio (1:0.88) was significant from the 1:1 ratio and month has significant effect on the distribution of different sexes $\left(\chi^{2}\right.$-test, $\mathrm{P}<0.01,99 \%$ Table 7$)$. Fecundity variation relative to carapace width was fitted into a power function given by the equation $F=1121 . x-6859$ and yielded a correlation coefficient of $R^{2}=0.909$. The scatter plot representing this correlation is shown on Figure 3. Fecundity variation of both species in respect of carapace width and number of eggs was correlated and the result exposed for $U$. lactea annulipes (significance of $\mathrm{r}$ at $5 \%=0.312$ and significance of $\mathrm{r}$ at $1 \%=0.403$ ) and $U$. triangularis bengali (significance of rat $5 \%=0.320$ and significance of rat $1 \%=0.413$ ) (Table 8).

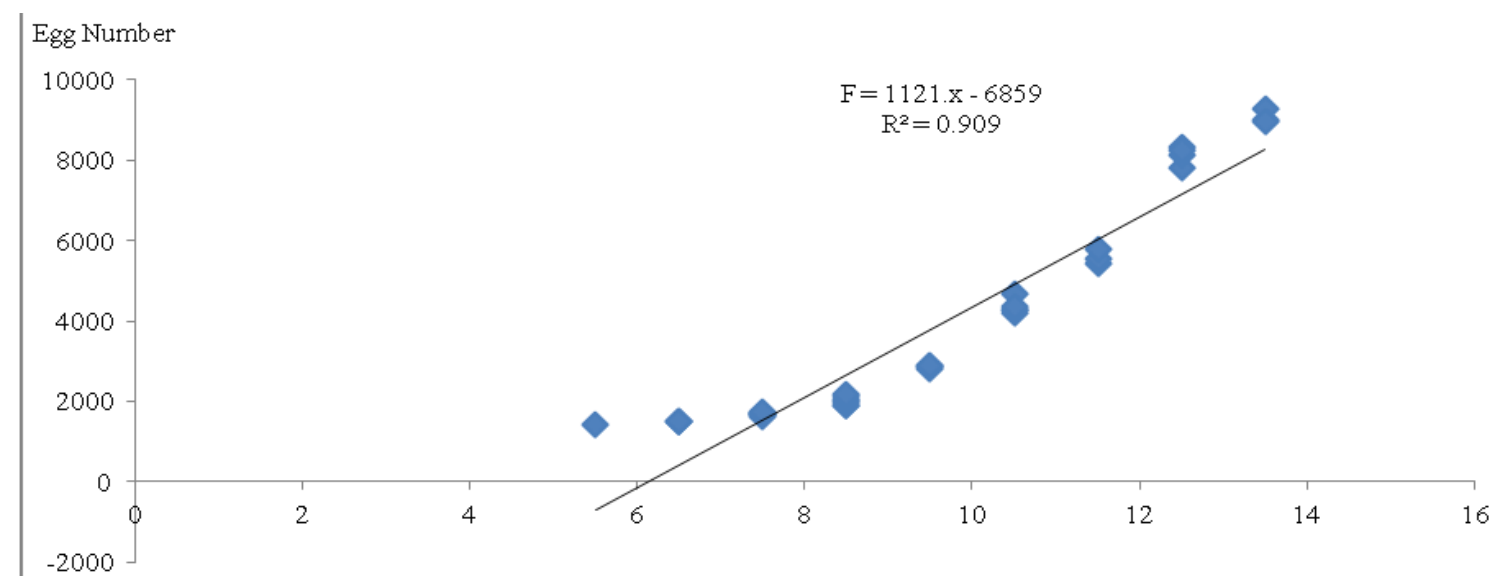

Figure 3. Relation between egg number and carapace width of $U$. triangularis bengali $(\mathrm{F}=$ fecundity, $\mathrm{R}^{2}=$ determination coefficient, $\mathrm{X}$ axis=carapace width, $\mathrm{Y}$ axis=Egg Number)

Table 2. Number of individuals, percentage and sex ratios of Uca lactea annulipes

\begin{tabular}{|c|c|c|c|c|c|c|c|c|}
\hline Months & Mal (N) & $\%$ & NOF $(\mathrm{N})$ & $\%$ & OF $(\mathrm{N})$ & $\%$ & Total $(\mathrm{N})$ & Sex ratio (M:F) \\
\hline Mar.'08 & 50 & 41.32 & 15 & 12.40 & 56 & 46.28 & 121 & $1: 1.42$ \\
\hline Apr.'08 & 62 & 41.33 & 25 & 16.67 & 63 & 42.00 & 150 & $1: 1.42$ \\
\hline May,'08 & 42 & 48.84 & 32 & 37.21 & 12 & 13.95 & 86 & $1: 1.05$ \\
\hline Jun.'08 & 72 & 72.00 & 28 & 28.00 & 0 & 0 & 100 & $1: 0.39$ \\
\hline Jul.'08 & 68 & 79.07 & 18 & 20.93 & 0 & 0 & 86 & $1: 0.26$ \\
\hline Aug.'08 & 84 & 79.25 & 22 & 20.75 & 0 & 0 & 106 & $1: 0.26$ \\
\hline Sept.'08 & 95 & 84.07 & 18 & 15.93 & 0 & 0 & 113 & $1: 0.19$ \\
\hline Oct.'08 & 49 & 37.12 & 28 & 21.21 & 55 & 41.67 & 132 & $1: 1.69$ \\
\hline Nov.'08 & 51 & 47.22 & 8 & 7.41 & 49 & 45.37 & 108 & $1: 1.12$ \\
\hline
\end{tabular}




\begin{tabular}{|c|c|c|c|c|c|c|c|c|}
\hline Dec.'08 & 57 & 49.14 & 0 & 0 & 59 & 50.86 & 116 & $1: 1.04$ \\
\hline Jan.'09 & 66 & 57.89 & 44 & 38.60 & 4 & 3.51 & 114 & $1: 0.73$ \\
\hline Feb.'09 & 56 & 69.14 & 23 & 28.40 & 2 & 2.47 & 81 & $1: 0.45$ \\
\hline Total & 752 & 57.27 & 261 & 19.88 & 300 & 22.85 & 1313 & $1: 0.75$ \\
\hline
\end{tabular}

Mal, males; NOF, non-ovigerous females; OF, ovigerous females; M, males; F, females; N, Sample size.

Table 3. U. lactea annulipes; Mean fecundity (X) and Standard deviation registered for ovigerous females size classes $(\mathrm{CW})(\mathrm{N}=40 ; \mathrm{CW}=$ carapace width $)$

\begin{tabular}{|c|c|c|}
\hline Size Class $(\mathrm{mm})$ & $\mathrm{X} \pm \mathrm{SD}$ & $\mathrm{N}$ \\
\hline $5.5-6.5$ & $1818 \pm 60$ & 3 \\
\hline $6.5-7.5$ & $2230 \pm 201$ & 7 \\
\hline $7.5-8.5$ & $3487 \pm 255$ & 6 \\
\hline $8.5-9.5$ & $4582 \pm 442$ & 5 \\
\hline $9.5-10.5$ & $6187 \pm 179$ & 6 \\
\hline $10.5-11.5$ & $7481 \pm 581$ & 4 \\
\hline $11.5-12.5$ & $9730 \pm 1395$ & 3 \\
\hline $12.5-13.5$ & $12070 \pm 1156$ & 3 \\
\hline $13.5-14.5$ & $13283 \pm 480$ & 3 \\
\hline
\end{tabular}

Table 4. The result of Chi square $\left(\chi^{2}\right.$-test, $\left.\mathrm{P}<0.01\right)$ analysis of $U$. lactea annulipes between months and distribution of different sexes

\begin{tabular}{|l|l|l|l|}
\hline Chi-Square Tests \\
\hline & value & df & Asymp. Sig.(2- sided) \\
\hline Pearson Chi-Square & $404.208^{\text {a }}$ & 22 & .000 \\
\hline Likelihood Ratio & 503.210 & 22 & .000 \\
\hline N of Valid Cases & 1313 & & \\
\hline a. 0 cells (.0\%) have expected count. The minimum expected count is 16.10. \\
\hline
\end{tabular}

Table 5. Number of individuals, percentage and sex ratios of Uca triangularis bengali

\begin{tabular}{|c|c|c|c|c|c|c|c|c|}
\hline Months & Mal (N) & $\%$ & NOF $(\mathrm{N})$ & $\%$ & OF $(\mathrm{N})$ & $\%$ & Total (N) & Sex ratio (M:F) \\
\hline Mar.'08 & 45 & 78.95 & 12 & 21.05 & 0 & 0 & 57 & $1: 0.27$ \\
\hline Apr.'08 & 32 & 69.57 & 14 & 30.43 & 0 & 0 & 46 & $1: 0.44$ \\
\hline May,'08 & 28 & 71.79 & 11 & 28.21 & 0 & 0 & 39 & $1: 0.39$ \\
\hline Jun.'08 & 36 & 52.94 & 32 & 47.06 & 0 & 0 & 68 & $1: 0.89$ \\
\hline Jul.'08 & 24 & 36.36 & 42 & 63.64 & 0 & 0 & 66 & $1: 1.75$ \\
\hline Aug.'08 & 28 & 62.22 & 17 & 3.78 & 0 & 0 & 45 & $1: 0.61$ \\
\hline Sept.'08 & 21 & 65.63 & 11 & 34.38 & 0 & 0 & 32 & $1: 0.52$ \\
\hline Oct.'08 & 19 & 29.69 & 1 & 1.56 & 44 & 68.75 & 64 & $1: 2.37$ \\
\hline Nov.'08 & 22 & 40.74 & 0 & 0 & 32 & 59.26 & 54 & $1: 1.45$ \\
\hline Dec.'08 & 14 & 43.75 & 0 & 0 & 18 & 56.25 & 32 & $1: 1.29$ \\
\hline Jan.'09 & 11 & 33.33 & 14 & 42.42 & 8 & 24.24 & 33 & $1: 2$ \\
\hline Feb.'09 & 16 & 80.00 & 4 & 20.00 & 0 & 0 & 20 & $1: 0.25$ \\
\hline Total & 296 & 53.24 & 158 & 28.42 & 102 & 18.35 & 556 & $1: 0.88$ \\
\hline
\end{tabular}

Table 6. U. triangularis bengali; Mean fecundity $(\mathrm{X})$ and Standard deviation registered for ovigerous females size classes $(\mathrm{CW})(\mathrm{N}=38 ; \mathrm{CW}=$ carapace width $)$

\begin{tabular}{|l|c|c|}
\hline Size Class $(\mathrm{mm})$ & $\mathrm{X} \pm \mathrm{SD}$ & $\mathrm{N}$ \\
\hline $5.5-6.5$ & $1472 \pm 43$ & 3 \\
\hline
\end{tabular}




\begin{tabular}{|l|l|l|}
\hline $6.5-7.5$ & $1651 \pm 64$ & 8 \\
\hline $7.5-8.5$ & $1961 \pm 133$ & 7 \\
\hline $8.5-9.5$ & $2674 \pm 345$ & 4 \\
\hline $9.5-10.5$ & $4065 \pm 683$ & 5 \\
\hline $10.5-11.5$ & $5105 \pm 653$ & 3 \\
\hline $11.5-12.5$ & $7512 \pm 1173$ & 4 \\
\hline $12.5-13.5$ & $8867 \pm 440$ & 4 \\
\hline
\end{tabular}

Table 7. The result of Chi square $\left(\chi^{2}\right.$-test, $\left.\mathrm{P}<0.01\right)$ analysis of $U$. triangularis bengali between months and distribution of different sexes

\begin{tabular}{|l|l|l|l|}
\hline Chi-Square Tests \\
\hline & value & df & Asymp. Sig.(2- sided) \\
\hline Pearson Chi-Square & $346.523^{\mathrm{a}}$ & 22 & .000 \\
\hline Likelihood Ratio & 378.551 & 22 & .000 \\
\hline N of Valid Cases & 556 & & \\
\hline a. 1 cells (2.8\%) have expected count less than 5.The minimum expected count is 3.67 \\
\hline
\end{tabular}

Table 8 . The result of correlation coefficient analysis in between carapace width and number of eggs

\begin{tabular}{|c|c|c|c|}
\hline \multicolumn{2}{|c|}{ Uca lactea annulipes } & \multicolumn{2}{|c|}{ Uca triangularis bengali } \\
\hline \multicolumn{2}{|l|}{$\mathrm{CW}(\mathrm{mm})$} & \multicolumn{2}{|l|}{$\mathrm{CW}(\mathrm{mm})$} \\
\hline $\mathrm{CW}(\mathrm{mm})$ & 1 & $\mathrm{CW}(\mathrm{mm})$ & 1 \\
\hline No of eggs & 0.975 & No of eggs & 0.954 \\
\hline \multicolumn{2}{|c|}{ significance of rat $5=0.312$} & significance of rat & $5 \%=0.320$ \\
\hline significanc & rat $1 \%=0.403$ & significance of rat & $1 \%=0.413$ \\
\hline
\end{tabular}

\subsection{Different Characteristics of Bioturbation}

\subsubsection{Burrow Depth and Diameter}

All burrows of $U$. lactea annulipes contain air in the upper two-third parts and water only in the lowest one third part. During high tide, the burrow entrances remained totally closed with mud. The maximum depth of the burrow $(0.941 \mathrm{~m})$ was noticed at HTL during pre-monsoon and the minimum depth $(0.340 \mathrm{~m})$ was recorded at LTL during monsoon. The maximum burrow diameter $(0.032 \mathrm{~m})$ was recorded during monsoon at LTL and that of minimum $(0.008 \mathrm{~m})$ was found during pre-monsoon at HTL. The maximum depth $(0.858 \mathrm{~m})$ of the burrow of $U$. triangularis bengali was observed at HTL during pre-monsoon and the minimum depth $(0.338$ $\mathrm{m})$ was recorded at LTL during monsoon. The maximum burrow diameter $(0.028 \mathrm{~m})$ was recorded during monsoon at LTL and that of minimum $(0.006 \mathrm{~m})$ was observed during post monsoon at HTL (Table 9).

\subsubsection{Semidome and Mudball}

Semidome is a roof covering a semicircular space i.e. half a dome. Only male U. lactea annulipes could construct semidomes by scrapping up bits of sediments from the surface with their first four walking legs on the side with the major claw, and depositing the sediment 


\section{Macrothink}

Journal of Biology and Life Science ISSN 2157-6076 2014, Vol. 5, No. 2

materials around the burrow entrance displaying triangular shape (Figures 4A and 4B) which tended to become completely invisible during post monsoon at HTL throughout the study period. The maximum height of semidome $(0.049 \mathrm{~m})$ was recorded during monsoon at LTL and the minimum height $(0.003 \mathrm{~m})$ was documented during pre-monsoon at HTL. U. triangularis bengali also made mudball (Figure 5) which was composed of large wet soil pellets and the diameter of mudballs ranged from $0.013 \mathrm{~m}$ at MTL during post-monsoon to $0.001 \mathrm{~m}$ at HTL during monsoon (Table 9).
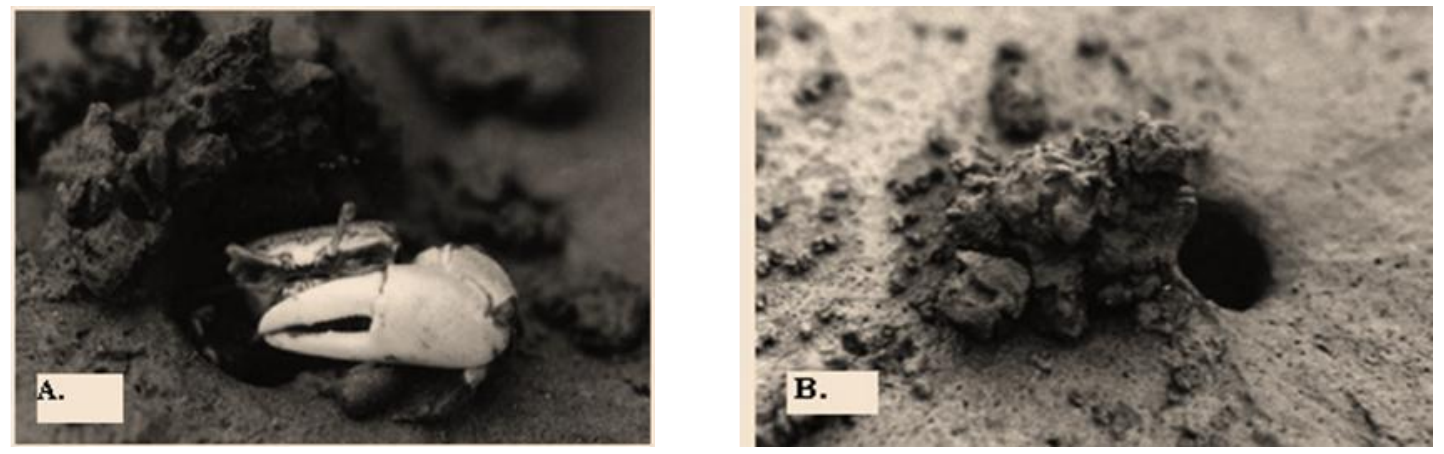

Figure 4. A. Uca lactea annulipes with a semidome, B. Lateral view of a semidome

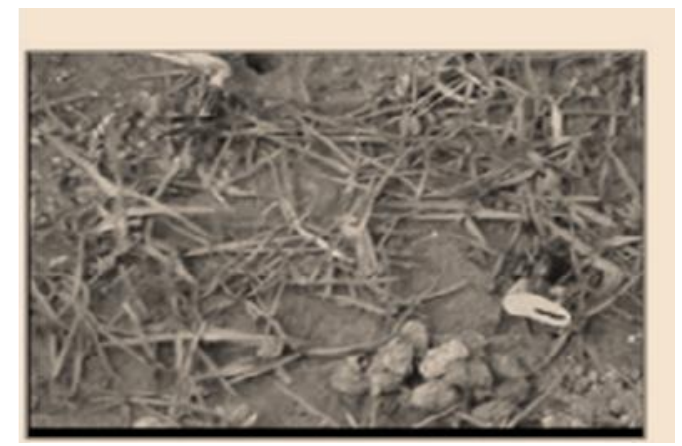

Figure 5. Uca triangularis bengali with mudball

\subsubsection{Seasonal Variation in Quantity of Excavated Mud}

In $U$. lactea annulipes, the weight of the excavated mud varied from $0.063 \mathrm{~kg}$ at MTL during pre monsoon to $0.182 \mathrm{~kg}$ at LTL during monsoon and the same in $U$. triangularis bengali varied from to $0.055 \mathrm{~kg}$ at MTL during post monsoon to $0.162 \mathrm{~kg}$ at LTL during monsoon (Table 9) respectively.

\subsubsection{Seasonal Variation in Distance (M) of Placement of Excavated Mud}

The distance of placement of mudballs of $U$. lactea annulipes also varied from $0.057 \mathrm{~m}$ at HTL during pre-monsoon to $0.165 \mathrm{~m}$ at LTL during monsoon. The mudballs prepared by $U$. triangularis bengali were thrown to place of a distance of $0.039 \mathrm{~m}$ at HTL during post monsoon to $0.086 \mathrm{~m}$ at LTL during monsoon (Table 9).

3.3.5 Seasonal Variation in Frequency of Placement of Mudballs / 900 Seconds 


\section{Macrothink $\Delta$ Institute ${ }^{m}$}

Journal of Biology and Life Science ISSN 2157-6076 2014, Vol. 5, No. 2

$U$. lactea annulipes exihibited highest value in respect of frequency of placement of mudballs (38.50 times) at LTL during monsoon and minimum value (1.00 times) at HTL during post monsoon. In $U$. triangularis bengali, the frequency of placement of mudball was maximum (29.60 times) at LTL during monsoon and minimum (3.90 times) at HTL during post monsoon (Table 9).

Table 9. Seasonal variations in different characteristics of bioturbation

\begin{tabular}{|c|c|c|c|c|c|c|c|c|c|c|}
\hline \multirow{2}{*}{$\begin{array}{l}\text { SL. } \\
\text { No. }\end{array}$} & \multirow[t]{2}{*}{ Species } & \multicolumn{3}{|c|}{ Pre monsoon } & \multicolumn{3}{|c|}{ Monsoon } & \multicolumn{3}{|c|}{ Post monsoon } \\
\hline & & LTL & MTL & HTL & LTL & MTL & HTL & LTL & MTL & HTL \\
\hline \multirow[t]{3}{*}{1} & \multicolumn{10}{|l|}{ Burrow depth (m) } \\
\hline & $\begin{array}{l}\text { U. lactea } \\
\text { annulipes }\end{array}$ & 0.495 & 0.647 & 0.941 & 0.340 & 0.400 & 0.465 & 0.357 & 0.412 & 0.615 \\
\hline & $\begin{array}{l}U . \text { triangularis } \\
\text { bengali }\end{array}$ & 0.519 & 0.652 & 0.858 & 0.338 & 0.406 & 0.501 & 0.381 & 0.457 & 0.546 \\
\hline \multirow[t]{3}{*}{2} & \multicolumn{10}{|c|}{ Burrow diameter $(\mathrm{m})$} \\
\hline & $\begin{array}{l}\text { U. lactea } \\
\text { annulipes }\end{array}$ & 0.022 & 0.017 & 0.008 & 0.032 & 0.024 & 0.018 & 0.014 & 0.015 & 0.012 \\
\hline & $\begin{array}{l}\text { U. triangularis } \\
\text { bengali }\end{array}$ & 0.026 & 0.018 & 0.013 & 0.028 & 0.025 & 0.018 & 0.021 & 0.018 & 0.006 \\
\hline \multirow[t]{3}{*}{3} & \multicolumn{10}{|c|}{ Height / diameter of bioturbatory structures (m) } \\
\hline & $\begin{array}{l}\text { Semidome } \\
\text {-Height } \\
\text { U. lactea } \\
\text { annulipes }\end{array}$ & 0.005 & 0.004 & 0.003 & 0.049 & 0.029 & 0.025 & 0.007 & 0.006 & 0 \\
\hline & $\begin{array}{l}\text { Mudball- } \\
\text { Diameter } \\
U \text {.triangularis } \\
\text { bengali }\end{array}$ & 0.008 & 0.007 & 0.006 & 0.003 & 0.003 & 0.001 & 0.009 & 0.013 & 0.004 \\
\hline \multirow[t]{3}{*}{4} & \multicolumn{10}{|c|}{ Excavated mud (in terms of weight-kg) } \\
\hline & $\begin{array}{l}U . \quad \text { lactea } \\
\text { annulipes }\end{array}$ & 0.071 & 0.063 & 0.070 & 0.182 & 0.167 & 0.146 & 0.094 & 0.083 & 0.068 \\
\hline & $\begin{array}{l}U \text {.triangularis } \\
\text { bengali }\end{array}$ & 0.091 & 0.081 & 0.073 & 0.162 & 0.137 & 0.122 & 0.071 & 0.055 & 0.056 \\
\hline \multirow[t]{3}{*}{5} & \multicolumn{10}{|c|}{ Distance of placement of excavated mudball (m) } \\
\hline & $\begin{array}{l}\text { U. lactea } \\
\text { annulipes }\end{array}$ & 0.086 & 0.060 & 0.057 & 0.165 & 0.156 & 0.064 & 0.105 & 0.092 & 0.095 \\
\hline & $\begin{array}{l}\text { U.triangularis } \\
\text { bengali }\end{array}$ & 0.079 & 0.064 & 0.049 & 0.086 & 0.067 & 0.064 & 0.069 & 0.049 & 0.039 \\
\hline 6 & \multicolumn{10}{|c|}{ Frequency of mudball placement / $900 \mathrm{~s}$} \\
\hline & $\begin{array}{l}\text { U. lactea } \\
\text { annulipes }\end{array}$ & 20.50 & 12.30 & 7.70 & 38.50 & 17.80 & 9.50 & 13.60 & 10.80 & 1.00 \\
\hline & $\begin{array}{l}\text { U. triangularis } \\
\text { bengali }\end{array}$ & 13.70 & 10.30 & 5.90 & 29.60 & 20.50 & 11.60 & 12.50 & 7.40 & 3.90 \\
\hline
\end{tabular}


3.4 Results of ANOVA Analyses and Duncan's Test on Different forms of Bioturbation

\subsubsection{Uca lactea annulipes}

\subsubsection{Anova Analyses}

\subsubsection{A. Seasons Wise}

ANOVA analyses showed that main effect of season was found to be significant at $1 \%$ level of significance due to burrow diameter, height of semidome, weight of excavated mud, distance and frequency of placement of excavated mud, and significant at $5 \%$ level of significance on burrow depth (Table 10).

\subsubsection{B. Tidal Levels Wise}

ANOVA analyses displayed that main effect of tidal level was found significant at $1 \%$ level of significance due to burrow depth, burrow diameter, height of semidome, and weight of excavated mud, distance and frequency of placement of excavated mud (Table 10).

\subsubsection{C. Seasons and Tidal Levels Wise}

ANOVA analyses revealed that main effect of season and tidal level exhibited significant at $1 \%$ level of significance due to height of semidome, weight of excavated mud, distance and frequency of placement of excavated mud respectively (Table 10).

\subsubsection{Results on Duncan's Test}

\subsubsection{A. Seasonal Effect of Different Characteristics of Bioturabation at Different Seasons}

The main effects of seasons when compared by Duncan's test at 5\% level of significance, it was found that the mean of burrow depth displayed significantly higher during pre-monsoon than monsoon and post monsoon; burrow diameter exhibited significantly higher results during monsoon than pre monsoon and post monsoon; height of semidome demonstrated significantly higher values during monsoon than pre monsoon and post monsoon; weight of excavated matters revealed significantly higher results during monsoon than post monsoon than pre monsoon; distance of placement of excavated mud demonstrated significantly higher results during monsoon than post monsoon than pre monsoon and frequency of placement of excavated matters showed higher values during monsoon than pre monsoon than post monsoon, (Table 11) respectively.

\subsubsection{B. Seasonal Effect of Different Characteristics of Bioturabation at Different Tidal} Levels

The main effects of tidal levels when compared by Duncan's test at 5\% level of significance, it was resulted that the mean of burrow depth showed significantly higher values at HTL than LTL and MTL; burrow diameter obtained significantly higher results at LTL than MTL than HTL; height of semidome displayed significantly higher values at LTL than MTL than HTL; weight of excavated mud exposed significantly higher findings at MTL than LTL and HTL; distance of placement and frequency of placement of excavated mud revealed significantly higher values at LTL than MTL than HTL (Table 11) respectively. 
Table 10. The result of ANOVA analysis of different characteristics of bioturabation of $U$. lactea annulipes

\begin{tabular}{|c|c|c|c|c|c|c|}
\hline Source & Variable & SS & $\mathrm{df}$ & MS & $\mathrm{F}$ & Sig. \\
\hline \multirow{6}{*}{ SEASONS } & Burrow Depth & 1712.37 & 2 & 856.18 & 7.34 & $0.013^{*}$ \\
\hline & Burrow Diameter & 3.84 & 2 & 1.92 & 35.10 & $0.00 * *$ \\
\hline & Height of semidome & 33.54 & 2 & 16.77 & 406.42 & $00.00 * *$ \\
\hline & Weight of Excavated mud & 33621.50 & 2 & 16810.75 & 8865.70 & $00.00 * *$ \\
\hline & Distance of placement of excavated mudball & 143.61 & 2 & 71.80 & 86.37 & $00.00 * *$ \\
\hline & Frequency of mudball placement & 581.37 & 2 & 290.68 & 284.91 & $00.00^{* *}$ \\
\hline \multirow[t]{6}{*}{ TIDAL LEVELS } & Burrow Depth & 2391.68 & 2 & 1195.84 & 10.25 & $0.005^{* *}$ \\
\hline & Burrow Diameter & 2.10 & 2 & 1.05 & 19.20 & $0.001 * *$ \\
\hline & Height of semidome & 3.00 & 2 & 1.50 & 36.29 & $00.00 * *$ \\
\hline & Weight of Excavated mud & 1323.20 & 2 & 661.60 & 348.92 & $00.00 * *$ \\
\hline & Distance of placement of excavated mudball & 59.34 & 2 & 29.67 & 35.69 & $00.00 * *$ \\
\hline & Frequency of mudball placement & 1052.96 & 2 & 526.48 & 516.03 & $00.00^{* *}$ \\
\hline \multirow[t]{6}{*}{$\begin{array}{l}\text { SEASONS } \\
\text { TIDAL LEVELS }\end{array}$} & Burrow Depth & 241.93 & 4 & 60.48 & 0.52 & $0.725 \mathrm{NS}$ \\
\hline & Burrow Diameter & 0.55 & 4 & 0.14 & 2.50 & $0.117 \mathrm{NS}$ \\
\hline & Height of semidome & 2.18 & 4 & 0.55 & 13.22 & $0.001 * *$ \\
\hline & Weight of Excavated mud & 797.30 & 4 & 199.33 & 105.12 & $00.00^{* *}$ \\
\hline & Distance of placement of excavated mudball & 69.86 & 4 & 17.46 & 21.01 & $00.00^{* *}$ \\
\hline & Frequency of mudball placement & 217.75 & 4 & 54.44 & 53.36 & $00.00 * *$ \\
\hline \multirow[t]{6}{*}{ Error } & Burrow Depth & 1049.84 & 9 & 116.65 & & \\
\hline & Burrow Diameter & 0.49 & 9 & 0.05 & & \\
\hline & Height of semidome & 0.37 & 9 & 0.04 & & \\
\hline & Weight of Excavated mud & 17.07 & 9 & 1.90 & & \\
\hline & Distance of placement of excavated mudball & 7.48 & 9 & 0.83 & & \\
\hline & Frequency of mudball placement & 9.18 & 9 & 1.02 & & \\
\hline \multirow[t]{6}{*}{ Total } & Burrow Depth & 5395.81 & 17 & & & \\
\hline & Burrow Diameter & 6.98 & 17 & & & \\
\hline & Height of semidome & 39.09 & 17 & & & \\
\hline & Weight of Excavated mud & 35759.07 & 17 & & & \\
\hline & Distance of placement of excavated mud & 280.29 & 17 & & & \\
\hline & Frequency of mudball placement & 1861.25 & 17 & & & \\
\hline
\end{tabular}

*Significant of 0.05 level ** Significant of 0.01 level NS- Not Significant

Table 11. Duncan's test of different characteristics of bioturabation of $U$. lactea annulipes between seasons and tidal levels

\begin{tabular}{|c|c|c|c|c|c|c|c|}
\hline Seasons & $\begin{array}{l}\text { Tidal } \\
\text { Levels }\end{array}$ & $\begin{array}{l}\text { Burrow } \\
\text { Depth }\end{array}$ & $\begin{array}{l}\text { Burrow } \\
\text { Diameter }\end{array}$ & $\begin{array}{l}\text { Height of } \\
\text { Semidome }\end{array}$ & $\begin{array}{l}\text { Weight of } \\
\text { Excavated } \\
\text { mud }\end{array}$ & $\begin{array}{ll}\text { Distance } & \text { of } \\
\text { placement } & \text { of } \\
\text { excavated mud } & \end{array}$ & $\begin{array}{l}\text { Frequency of } \\
\text { mudball } \\
\text { placement }\end{array}$ \\
\hline \multirow[t]{4}{*}{ Pre monsoon } & HTL & 89.00 & 1.000 & 0.420 & 71.250 & 5.760 & 8.030 \\
\hline & LTL & 52.78 & 1.950 & 0.605 & 71.185 & 8.900 & 21.765 \\
\hline & MTL & 64.13 & 1.550 & 0.490 & 64.110 & 6.145 & 12.620 \\
\hline & Total & $68.63 \mathrm{a}$ & $1.50 \mathrm{~b}$ & $0.51 \mathrm{~b}$ & $68.85 c$ & $6.94 \mathrm{c}$ & $14.14 b$ \\
\hline \multirow[t]{4}{*}{ Monsoon } & HTL & 61.250 & 1.700 & 2.570 & 147.790 & 7.625 & 10.390 \\
\hline & LTL & 37.975 & 2.975 & 4.575 & 184.615 & 17.660 & 39.225 \\
\hline & MTL & 55.875 & 2.300 & 3.050 & 167.410 & 16.150 & 18.545 \\
\hline & Total & $51.70 \mathrm{~b}$ & $2.33 \mathrm{a}$ & $3.40 \mathrm{a}$ & $166.61 \mathrm{a}$ & $13.81 \mathrm{a}$ & $22.72 \mathrm{a}$ \\
\hline \multirow[t]{2}{*}{$\begin{array}{l}\text { Post } \\
\text { monsoon }\end{array}$} & HTL & 60.000 & 1.050 & 0.000 & 68.495 & 9.885 & 1.190 \\
\hline & LTL & 35.125 & 1.325 & 0.795 & 94.645 & 9.890 & 14.495 \\
\hline
\end{tabular}




\section{Ml Macrothink}

\begin{tabular}{|l|l|l|l|l|l|l|l|}
\hline & MTL & 41.588 & 1.350 & 0.705 & 84.480 & 9.365 & 11.125 \\
\hline & Total & $45.57 \mathrm{~b}$ & $1.24 \mathrm{~b}$ & $0.50 \mathrm{~b}$ & $82.54 \mathrm{~b}$ & $9.71 \mathrm{~b}$ & $8.94 \mathrm{c}$ \\
\hline \multicolumn{8}{|c|}{} \\
\hline Total & HTL & $70.08 \mathrm{x}$ & $1.25 \mathrm{z}$ & $1.00 \mathrm{z}$ & $95.85 \mathrm{z}$ & $7.76 \mathrm{z}$ & $6.54 \mathrm{z}$ \\
\hline & LTL & $41.96 \mathrm{y}$ & $2.08 \mathrm{x}$ & $1.99 \mathrm{x}$ & $116.82 \mathrm{x}$ & $12.15 \mathrm{x}$ & $25.16 \mathrm{x}$ \\
\hline & MTL & $53.86 \mathrm{y}$ & $1.73 \mathrm{y}$ & $1.42 \mathrm{y}$ & $105.33 \mathrm{y}$ & $10.55 \mathrm{y}$ & $14.10 \mathrm{y}$ \\
\hline
\end{tabular}

\subsubsection{Uca triangularis bengali}

\subsubsection{Anova Analyses}

\subsubsection{A. Seasons Wise}

ANOVA analyses established that main effect of season was found significant at $1 \%$ level of significance due to burrow diameter, mudball diameter, weight of excavated mud, distance and frequency of placement of excavated mud, and significant at 5\% level of significance on burrow depth (Table 12).

\subsubsection{B. Tidal Levels Wise}

ANOVA analyses displayed that main effect of tidal level was found significant at $1 \%$ level of significance due to mudball diameter, distance and frequency of placement of excavated mud, and only burrow diameter revealed significant at $5 \%$ level of significance (Table 12).

\subsubsection{C. Seasons And Tidal Levels Wise}

ANOVA analyses revealed that main effect of season and tidal level was found significant at $1 \%$ level of significance on mudball diameter and frequency of placement of mudball (Table 12).

\subsubsection{Results on Duncan's Test}

\subsubsection{A. Seasonal effect of different characteristics of bioturabation at different seasons}

The main effects of seasons when compared by Duncan's test at 5\% level of significance, it was established that the mean of burrow depth displayed significantly higher effects during pre monsoon than post monsoon; burrow diameter exhibited significantly higher impact during monsoon than pre monsoon and post monsoon; mudball diameter established significantly higher results during post monsoon than pre monsoon than monsoon; weight of excavated mud exhibited significantly higher role during monsoon than post monsoon and pre monsoon; distance of placement of excavated mud revealed significantly higher values during monsoon than post monsoon and frequency of placement of mudball showed higher results during monsoon than pre monsoon than post monsoon (Table 13) respectively.

\subsubsection{B. Seasonal effect of different characteristics of bioturabation at different tidal levels}

The main effects of tidal levels when compared by Duncan's test at 5\% level of significance, it was found that the mean of burrow depth showed significantly higher impacts at HTL than LTL; burrow diameter exhibited significantly higher results at LTL and MTL than HTL; mudball diameter displayed significantly higher values at MTL than LTL than HTL; weight of excavated mud showed significantly higher findings at LTL and MTL than HTL; distance of 
placement of excavated mud showed significantly higher influence at LTL than MTL and HTL and frequency of placement mudball revealed significantly higher results at LTL than MTL than HTL (Table 13) respectively.

Table 12. The result of ANOVA analysis of different characteristics of bioturabation of $U$. triangularis bengali

\begin{tabular}{|c|c|c|c|c|c|c|}
\hline Source & Variable & SS & $\mathrm{df}$ & MS & $\mathrm{F}$ & Sig. \\
\hline \multirow{6}{*}{ SEASONS } & Burrow Depth & 1886.71 & 2 & 943.36 & 5.019 & $0.034 *$ \\
\hline & Burrow Diameter & 3.45 & 2 & 1.72 & 9.856 & $0.005 * *$ \\
\hline & Diameter of mudball & 1.31 & 2 & 0.66 & 103.572 & $00.00 * *$ \\
\hline & Weight of Excavated mud & 13788.11 & 2 & 6894.05 & 25.258 & $00.00 * *$ \\
\hline & Distance of placement of excavated mud & 8.21 & 2 & 4.11 & 4.946 & $00.00 * *$ \\
\hline & Frequency of mudball placement & 571.66 & 2 & 285.83 & 124.070 & $00.00 * *$ \\
\hline \multirow[t]{6}{*}{ TIDAL LEVELS } & Burrow Depth & 1523.92 & 2 & 761.96 & 4.054 & $0.056 \mathrm{NS}$ \\
\hline & Burrow Diameter & 2.66 & 2 & 1.33 & 7.595 & $0.012 *$ \\
\hline & Diameter of mudball & 0.55 & 2 & 0.27 & 43.225 & $00.00 * *$ \\
\hline & Weight of Excavated mud & 1658.01 & 2 & 829.01 & 3.037 & $0.098 \mathrm{NS}$ \\
\hline & Distance of placement of excavated mud & 26.10 & 2 & 13.05 & 15.727 & $0.001 * *$ \\
\hline & Frequency of mudball placement & 344.58 & 2 & 172.29 & 74.787 & $00.00 * *$ \\
\hline \multirow[t]{6}{*}{$\begin{array}{l}\text { SEASONS } \\
\text { TIDAL LEVELS }\end{array}$} & Burrow Depth & 137.70 & 4 & 34.42 & 0.183 & $0.941 \mathrm{NS}$ \\
\hline & Burrow Diameter & 0.21 & 4 & 0.05 & 0.301 & $0.87 \mathrm{NS}$ \\
\hline & Diameter of mudball & 0.46 & 4 & 0.11 & 18.023 & $00.00 * *$ \\
\hline & Weight of Excavated mud & 2484.80 & 4 & 621.20 & 2.276 & $0.141 \mathrm{NS}$ \\
\hline & Distance of placement of excavated mud & 0.90 & 4 & 0.22 & 0.270 & $0.89 \mathrm{NS}$ \\
\hline & Frequency of mudball placement & 79.91 & 4 & 19.98 & 8.671 & $0.004 * *$ \\
\hline \multirow[t]{6}{*}{ Error } & Burrow Depth & 1691.60 & 9 & 187.96 & & \\
\hline & Burrow Diameter & 1.57 & 9 & 0.18 & & \\
\hline & Diameter of mudball & 0.06 & 9 & 0.01 & & \\
\hline & Weight of Excavated mud & 2456.54 & 9 & 272.95 & & \\
\hline & Distance of placement of excavated mud & 7.47 & 9 & 0.83 & & \\
\hline & Frequency of mudball placement & 20.73 & 9 & 2.30 & & \\
\hline \multirow[t]{6}{*}{ Total } & Burrow Depth & 5239.93 & 17 & & & \\
\hline & Burrow Diameter & 7.89 & 17 & & & \\
\hline & Diameter of mudball & 2.38 & 17 & & & \\
\hline & Weight of Excavated mud & 20387.46 & 17 & & & \\
\hline & Distance of placement of excavated mud & 42.68 & 17 & & & \\
\hline & Frequency of mudball placement & 1016.88 & 17 & & & \\
\hline
\end{tabular}

Table 13. Duncan's test of different characteristics of bioturabation of $U$. triangularis bengali between seasons and tidal levels

\begin{tabular}{|l|l|l|l|l|l|l|l|}
\hline Seasons & $\begin{array}{l}\text { Tidal } \\
\text { Levels }\end{array}$ & $\begin{array}{l}\text { Burrow } \\
\text { Depth }\end{array}$ & $\begin{array}{l}\text { Burrow } \\
\text { Diameter }\end{array}$ & $\begin{array}{l}\text { Diameter of } \\
\text { mudball }\end{array}$ & $\begin{array}{l}\text { Weight of } \\
\text { Excavated } \\
\text { mud }\end{array}$ & $\begin{array}{l}\text { Distance of placement } \\
\text { of excavated mud }\end{array}$ & $\begin{array}{l}\text { Frequency of } \\
\text { mudball } \\
\text { placement }\end{array}$ \\
\hline $\begin{array}{l}\text { Pre } \\
\text { monsoon }\end{array}$ & HTL & 86.588 & 1.250 & 0.680 & 74.700 & 5.600 & 6.725 \\
\hline & LTL & 54.525 & 2.175 & 0.940 & 92.335 & 9.065 & 15.580 \\
\hline & MTL & 69.855 & 1.500 & 0.820 & 81.925 & 6.630 & 10.825 \\
\hline & Total & $70.32 \mathrm{a}$ & $1.64 \mathrm{~b}$ & $0.81 \mathrm{~b}$ & $82.99 \mathrm{~b}$ & $7.10 \mathrm{ab}$ & $11.04 \mathrm{~b}$ \\
\hline Monsoon & HTL & 66.988 & 1.750 & 0.220 & 103.330 & 6.715 & 12.945 \\
\hline & LTL & 48.675 & 2.700 & 0.415 & 151.730 & 9.195 & 30.675 \\
\hline & MTL & 58.350 & 2.550 & 0.380 & 151.540 & 6.945 & 21.895 \\
\hline
\end{tabular}




\section{I Macrothink}

Journal of Biology and Life Science

ISSN 2157-6076

2014, Vol. 5, No. 2

\begin{tabular}{|l|l|l|l|l|l|l|l|}
\hline & Total & $58.00 \mathrm{ab}$ & $2.33 \mathrm{a}$ & $0.34 \mathrm{c}$ & $135.53 \mathrm{a}$ & $7.62 \mathrm{a}$ & $21.84 \mathrm{a}$ \\
\hline $\begin{array}{l}\text { Post } \\
\text { monsoon }\end{array}$ & HTL & 53.963 & 0.750 & 0.515 & 77.540 & 4.815 & 6.480 \\
\hline & LTL & 36.725 & 1.675 & 0.950 & 82.030 & 7.400 & 12.025 \\
\hline & MTL & 45.050 & 1.410 & 1.460 & 56.920 & 5.780 & 8.465 \\
\hline & Total & $45.258 \mathrm{~b}$ & $1.28 \mathrm{~b}$ & $0.98 \mathrm{a}$ & $72.16 \mathrm{~b}$ & $6.00 \mathrm{~b}$ & $8.99 \mathrm{c}$ \\
\hline
\end{tabular}

\section{Discussion}

The two species of fiddler crabs under present study display adaptation vis-a-vis distribution in different tidal levels of an intertidal belt(Chakraborty\& Chowdhury,1992) .U. lactea annulipes lives in large populations on low lying sandy-muddy loamy sediments along the edges of streams which are always covered by even in small amplitude of high tides. Nutrient-rich filamentous algae, detritus and bacteria are deposited by the receding tide each day, giving this species an ample supply of fresh food. U. triangularis bengali inhabits in small patches on higher areas that are not covered by all high tides; their habitat can remain uncovered by tides for several consecutive days in each 14 days semi-lunar tidal cycle. The species therefore has temporally limited access to fresh food which may affect growth rates. The behavioural differences between the two species appear to be strongly related to their different habitats, as found in other fiddler crab species (Backwell et al., 2006). Although the active burrowing activities were observed for both the species, it was found to be less in the habitat for $U$. triangularis bengali where the sediment was hard. As in other fiddler crab species, these high burrows did not get damaged by incoming tides and remained intact for several days (Klassen \& Ens, 1993; Backwell et al., 2006). Furthermore, in the both sexes, the feeding rate of $U$. lactea annulipes was faster than $U$. triangularis bengali. Many other differences in between these two species were detected in respect of sizes,biomass and density.U. lactea annulipes was slightly bigger than $U$. triangularis bengali but they used to live at comparable densities. The sex-ratio of $U$. lactea annulipes was slight male biased, and the sex ratio is (M: F: 1:0.75.) In $U$. triangularis bengali, the bias was less pronounced, and the sex ratio is (M: F: 1:0.88.). Month has significant effect on the allocation of different sexes $\left(\chi^{2}\right.$-test, $\left.\mathrm{P}<0.01,99 \%\right)$ of both species. Reproductive intensity in brachyuran can be measured by quantifying the relative frequency of ovigerous females. According to Sastry (1983), the beginning and the duration of the reproductive period are dependent on the occurrence of favorable environmental conditions. The major controlling factors appear to be latitude, temperature, larval food availability, and intertidal zonation (Sastry, 1983). The breeding period becomes protected from cool to warm subtropical localities (Emmerson, 1994). Since most studies have been conducted in temperate region, seasonal breeding is well reported in several the literatures (Thurman II, 1985 for $U$. subcylindrica in U.S.A./Mexico; Murai et al., 1987 for U. lactea in Japan; Spivak et al., 1991 for $U$. uruguayensis in Argentina). Yet, the majority of tropical crabs breed continuously, i.e., throughout the year, or have prolonged breeding seasons compared to species at higher latitudes (Sastry, 1983). The reproduction in U. triangularis bengali was remarkably post monsoonal, with a pronounced activity from October to January, and a pause period from 
March to September, when the ovigerous females were not found. Beyond this, the more pronounced reproductive intensity for $U$. lactea annulipes occurred in the pre monsoon and post monsoon season. For $U$. lactea annulipes, ovigerous females were registered all the year round, with exception during June, July, August and September. For many fiddler crab species there is a close association between mating and incubation place and fecundity. Salmon (1987) suggested when mating was underground, the female showed high fecundity (like $U$. pugilator), but when it happened at the surface, a low egg number was produced (like with $U$. vocans). According to Thurman II (1985), the fecundity (size and number of eggs) for species of the genus Uca from tropical and temperate areas could vary according to environmental conditions. Nevertheless, fiddler crabs, which lived very near the rivers exhibited larger size and produced higher number of eggs; while semi terrestrial or totally terrestrial species have small size and resulted a low number of progenies. Fecundity differences were observed as much between both species as between individuals of the species. These differences were related to many factors: the weather during which females were collected; food availability; multiple spawning $\left(1^{\mathrm{a}}, 2^{\mathrm{a}}\right.$ or $3^{\mathrm{a}}$ spawning of reproductive cycle); individual variation on egg production and natural egg losses related to female activity on the surface (Costa and Negreiros-Fransozo, 1996). The ability of $U$. lactea annulipes producing a higher number of eggs when compared with $U$. triangularis bengali did not confirm with the larval production of the former species was higher. The probability of mechanical losses, related to feeding activity on the surface was higher $U$. lactea annulipes than $U$. triangularis bengali. These points could be clarified only after undertaking study on fertility potential of both species in relation to their abilty of eggs production. There was also a difference between the species in handedness. In U. lactea annulipes, there were equal numbers of left and right handed males, while in $U$. triangularis bengali was a significant skew to right handed males. While it is generally thought that female fiddler crabs feed faster than males because they have two feeding claws, it is not always true. Of the four studied species, Weis and Weis (2004) found this to hold in only two species. It was observed in the present study that in both $U$. lactea annulipes and $U$. triangularis bengali females fed faster than males. There was a very obvious difference in the structure building behaviour of these two species. U. lactea annulipes arranged mud at some distance from the burrow and built semidomes. Many $U c a$ species build structures such as pillars or hoods from moist sand or mud (Shepard, 1954), some of which play roles in attracting females (Shepard, 1954) or defining territory (Zucker, 1981; Weis \& Weis, 2004). Mud balls may be merely a by-product of burrow excavation (Klassen $\&$ Ens, 1993, but may also function as a signal (Zeil et al., 2006).

Some of the species in soft sediments are responsible for the structure and functioning of their habitats. These organisms, known as 'bioturbators', constantly disturb the sediment by burrowing and feeding. Their activities mix the sediment layers and cause substantial resuspension of the sediment and its transport by waves and current. At the same time, bioturbation enhances organic decomposition, nutrient cycling, redistribution of organic materials and oxygenation of sediments, rather as earthworms do on land. These changes greatly affect estuarine and seafloor habitats, with repercussions for the entire soft-sediment ecosystem (Chatterjee et al., 2008). Burford et al., (2001)has indicated that for $U$. tangeri males, mudballs mark territory and are attractive to females. While we do not know the significance of 
our observations of crabs arranging mud balls and placing them at a distance from burrows and has not tested the functions of semi-domes, mud ball, it is clear that these structures play some role in the social as well as sexual lives of the crabs involved. Future work will illuminate their various roles. The possible function of semidome building behavior is whether it reduces aggression or attracting females. Mudball formed by the male of $U$. triangularis bengali seems to be functioning as territory marking or female attraction. It seems that above mentioned different unique structures viz. Semidome and mudball of two species have diverse functional roles, but more intensive study is required to understand their functional as well as ecological significance.

Overall, the present study tried to provide a preliminary report on the habitat, sex ratio, fecundity and some unique features of bioturbatory activities of two species of fiddler crab. There were some similarities and some differences in the ecobiology of the two species of fiddler crabs studied here. The similarities were largely due to the strong effect of seasonal cycles on the bioturbation of the crabs. The differences seem to be related, in part, to the slightly different microhabitats used by the two species. The construction of semidome and mudball that probably play some roles in the social as well sexual lives of both $U$. lactea annulipes and $U$. triangularis bengali.

\section{Acknowledgements}

Authors are thankful to the authority of Vidyasagar University for providing library, laboratory and internet facilities. Research was funded by the Ministry of Environment and Forest, Government of India [Sanctioned No. 3/6/2001 - CSC (M) dated $5^{\text {th }}$ Nov.2001].

\section{References}

Backwell, P. R., \& Christy, J. H. (2000). Dishonest signalling in a fiddler crab. Proceedings of the Royal Society of London, 267, 719-724. http://dx.doi.org/10.1098/rspb.2000.1062

Backwell, P. R., Jennions M., Wada K., Murai, M., \& Christy, J. (2006). Synchronous waving in two species of fiddler crabs. Acta Ethologica, 9, 22-25. http://dx.doi.org/10.1007/s10211-005-0009-8

Burford, F. R. L., McGregor, P. K., \& Oliveira, R. F. (2001). Mudballing revisited: further investigations into the construction behaviour of male Uca tangeri. Behaviour, 138, 221-234. http://dx.doi.org/10.1163/15685390151074393

Chakraborty, S. K., \& Chaudhury, A. (1992). Ecological studies on the zonation of brachyuran crabs in a virgin mangrove island of Sundarbans, India. Journal of Marine Biological Association of India, 34, 189-194.

Chakraborty, S. K., Chatterjee, S., Dey, M. K., Bhakat, R. K., \& Paul, A. K. (2012). Ecological Changes of an Eco-rehabilitated Delta of Hooghly Estuary. Journal of Coastal Environment, $3(1), 9-28$.

Chatterjee, S., \& Chakraborty, S. K. (2014). Feeding Behaviour and Functional Role of Some Selected Species of Brachyuran Crabs in Nutrient Cycle at Coastal Belt of Midnapore (East), 
West Bengal, India. Journal of Biology and Life Science, 5(1), 106-129. http://dx.doi.org/10.5296/jbls.v5i1.4869

Chatterjee, S., Bhunia, G., \& Chakraborty, S. K. (2008). Bioturbation of Brachyuran crabs and its impact on coastal ecosystem of Midnapore district, West Bengal, India. In proceedings of Forth International Conference on Environmental Science and Technology, at Houston, Texas U.S.A. Pp: 133-148.

Christy, J. H., Backwell, P. R. Y., \& Goshima, S. (2001). The design and production of a sexual signal: hoods and hood building by male fiddler crabs Uca musica. Behaviour, 138, 1065-1083. http://dx.doi.org/10.1163/156853901753287145

Costa, T. M., \& Negreiros-Fransozo, M. L. (1996). Fecundidade de Callinectes danae Smith, 1869 (Crustacea, Decapoda, Portunidae) na região de Ubatuba (SP), Brasilian Archive of Biology and Technology, 39(2), 393-400.

Costa, T. M., Silva, S. M. J., \& Negreiros-Fransozo, M. L. (2006). Reproductive pattern comparison of Uca thayeri Rathbun, 1900 and U. uruguayensis Nobili, 1901 (Crustacea, Decapoda, Ocypodidae). Brazilian Archives of Biology and Technology, 49(1), 117-123. http://dx.doi.org/10.1590/S1516-89132006000100014

D'Andrea, A. F., \& DeWitt, T. H. (2009). Geochemical ecosystem engineering by the mud shrimp Upogebia pugettensis (Crustacea: Thalassinidae) in Yaquina Bay, Oregon: density-dependent effects on organic matter remineralization and nutrient cycling. Limnology and Oceanography, 54, 1911-1932. http://dx.doi.org/10.4319/lo.2009.54.6.1911

Daiber, F. C. (1952). Animals of the tidal marsh. Van Nostrand Reinhold, New York.pp. 422.

Emmerson W. D. (1994). Seasonal breeding cycles and sex-ratios of 8 species of crabs from Mgazana, a mangrove estuary in Transkei, southern Africa. Journal of Crustacean Biology, 14(3), 568-578. http://dx.doi.org/10.2307/1549002

Guillermo Guerao \& Guiomar Rotllant, (2009). Post-larval development and sexual dimorphism of the spider crab Maja brachydactyla (Brachyura: Majidae). Scientia Marina. http://dx.doi.org/10.3989/scimar.2009.73n4797

Hemmi, J. M., \& Zeil, J. (2003). Burrow surveillance in fiddler crabs II. The sensory cues. Journal of Experimental Biology, 206(22), 3951-3961. http://dx.doi.org/10.1242/jeb.00636

How, M. J., Hemmi, J. M., Zeil, J., \& Peters, R. (2008). Claw waving display changes with receiver distance in fiddler crabs, Uca perplexa. Animal Behaviour, 75(3), 1015-1022. http://dx.doi.org/10.1016/j.anbehav.2007.09.004

Johnson, P. T. J. (2003). Biased sex ratios in fiddler crabs (Brachyura, Ocypodidae): a review and evaluation of the influence of sampling method, size class and sex-specific mortality. Crustaceana, 76(5), 559-580. http://dx.doi.org/10.1163/156854003322316209

Klassen M., \& Ens, B. J. (1993). Habitat selection and energetics of the fiddler crab, Uca 
tangeri. Netherlands Journal of Sea Research, 31, 495-502. http://dx.doi.org/10.1016/0077-7579(93)90061-V

Koch, V., \& Wolff, M. (2002). Energy budget and ecological role of mangroveepibenthos in the Caeté estuary, North Brazil. Marine Ecology Progress Series, 228, 119-130. http://dx.doi.org/10.3354/meps228119

Lim, S. L. S. (2006). Fiddler crab burrow morphology: How do burrow dimensions and bioturbative activities compare in sympatric populations of Uca vocans (Linnaeus, 1758) and U. annulipes (H. Milne Edwards, 1837)? Crustaceana, 79(5), 525-540. http://dx.doi.org/10.1163/156854006777584241

Litulo, C. (2004). Reproductive aspects of a tropical populationof the fiddler crab Uca annulipes (H. Milne Edwards, 1837) (Brachyura: Ocypodidae) at Costa do Solmangrove, Maputo Bay, southern Mozambique. Hydrobiologia, 525, 167-175. http://dx.doi.org/10.1023/B:HYDR.0000038864.38435.6a

Macia A., Quincardete, I., \& Paula, J. (2001). A comparison of alternative methods for estimating population density of the fiddler crab Uca annulipes at Saco Mangrove, Inhaca $\begin{array}{llll}\text { Island } \quad \text { (Mozambique). } & \text { Hydrobiologia, } & \text { 449, }\end{array}$ http://dx.doi.org/10.1023/A:1017502817087

May, R. M. (1983). When to be which sex. Nature London, 301, 16-17. http://dx.doi.org/10.1038/301016a0

Mermillod-Blondin, F. (2011). The functional significance of bioturbation and biodeposition on biogeochemical processes at the water - sediment interfacein freshwater and marine ecosystems. Journal of North American Benthological Society, 30, 770-778. http://dx.doi.org/10.1899/10-121.1

Meysman, F. J. R., Middelburg, J. J., \& Heip, C. H. R. (2006). Bioturbation: a fresh look at Darwin's last idea. Trends in Ecology and Evolution, 21, 688-695. http://dx.doi.org/10.1016/j.tree.2006.08.002

Mokhtari, M., Savari A., Rezai H., Kochanian P., \& Bitaab, A. (2007). Population ecology of fiddler crab, Uca annulipes (Decapoda: Ocypodidae) in Sirik mangrove estuary, Iran. Estuarine, Coastal and Shelf Science, 76, 273-281. http://dx.doi.org/10.1016/j.ecss.2007.07.010

Montague, C. L. (1980). A natural history of temperate western Atlantic fiddler crabs (Genus Uca) with reference to their impact on the salt marsh. Contribution in Marine Science, 23, 25-55.

Murai, M., Goshima, S., \& Henmi, Y. (1987). Analysis of the mating system of the fiddler crab, Uca lactea. Animal Behaviour, 35, 1334-1342. http://dx.doi.org/10.1016/S0003-3472(87)80005-2

Pope, D. S. (2005).Waving in a crowd: fiddler crabs signal in networks. In: McGregor PK, ed. Animal communication networks. Cambridge: Cambridge University Press, 252-276. 
http://dx.doi.org/10.1017/CBO9780511610363.016

Reid, D. M., \& Corey, S. (1991). Comparative fecundity of decapod crustaceans, II. The fecundity of fifteen species of anomuran and brachyuran crabs. Crustaceana, 61(2), 175-189. http://dx.doi.org/10.1163/156854091X00669

Rosenberg, M. S. (2002). Fiddler crab claw shape variation: a geometric morphometric analysis across the genus Uca. Biological Journal of Linnean Society, 75, 147-162.

Salmon, M. (1987). On the reproductive behavior of the fiddler crab Uca thayeri, with comparisons to $U$. pugilator and $U$. vocans: evidence for behavioral convergence. Journal of Crustacean Biology, 7(1), 25-44. http://dx.doi.org/10.2307/1548623

Sastry, A. N. (1983). Ecological aspects of reproduction. In The biology of Crustacea. Environmental adaptations, vol. 8 (ed. F.J. Vernberg and G.W. Vernberg). pp. 179-270. New York: Academic Press.

Shepard, F. P. (1954). Nomenclature based on sand-silt-clay ratios. Journal of Sedimentary Petrology, 24, 151-158.

Spivak, E. D., Gavio, M. A., \& Navarro, C. E. (1991). Life history and structure of the word's southernmost Uca population: Uca uruguayensis (Crustacea, Brachyura) in Mar Chiquita lagoon (Argentina). Bulletin of Marine Science, 48(3), 679-688.

Statsoft, (2001). STATISTICA: data analysis software system, version 6.0. Tulsa, StatSoft, Inc.

Sweat, L. H. (2009). "Pachygrapsus transversus". Smithsonian Institution. http://www.sms.si.edu/irLspec /Pachyg transv.htm. Retrieved January 20, 2010.

Thurman II, C. L. (1985). Reproductive biology and population structure of the fiddler crab Uca subcylindrica (Stimpson). Biological Bulletin, 169, 215-229. http://dx.doi.org/10.2307/1541399

Weis J., \& Weis P. (2004). Behavior of four species of fiddler crabs, genus Uca, in southeast Sulawesi, $\quad$ Indonesia. $\quad H y d r o b i o l o g i a, \quad 57,58$. http://dx.doi.org/10.1023/B:HYDR.0000033093.84155.1d

Wilkinson, M. T., Richards P. J., \& Humphreys, G. S. (2009). Breaking ground: pedology, geological, and ecological implications of soil bioturbation. Earth Science Review, 97, 257-272. http://dx.doi.org/10.1016/j.earscirev.2009.09.005

Zar, J. H. (2009). Biostatistical Analysis. 5th ed. Pearson International Edition, Upper Saddle River.

Zeil J., Hemmi, J. M., \& Backwell, P. R. (2006). Fiddler crabs. Current Biology, 16, 40-41. http://dx.doi.org/10.1016/j.cub.2006.01.012

Zeil, J., \& Layne, J. E. (2002). Path integration in fiddler crabs and its relation to habitat and social life. In: Wiese K (ed.) Crustacean experimental systems in neurobiology. Springer, Berlin, Heidelberg, New York, pp. 227-24. http://dx.doi.org/10.1007/978-3-642-56092-7_13 


\section{Macrothink}

Zucker, N. (1981.) The role of hood-building in defining territoriesand limiting combat in fiddler crabs.

Animal

Behaviour,

29 ,

387-395.

http://dx.doi.org/10.1016/S0003-3472(81)80098-X

\section{Copyright Disclaimer}

Copyright for this article is retained by the author(s), with first publication rights granted to the journal.

This is an open-access article distributed under the terms and conditions of the Creative Commons Attribution license (http://creativecommons.org/licenses/by/3.0/). 